\title{
U-Pb SHRIMP data for the Madibe greenstone belt: implications for crustal growth on the western margin of the Kaapvaal Craton, South Africa
}

\author{
M. Poujol \\ Géosciences Rennes UMR6118, Université de Rennes 1, 35042 Rennes Cedex, France \\ e-mail: marc.poujol@univ-rennes1.fr
}

A.J. Hirner

School of Geosciences, CAMEG, Private Bag 3, University of the Witwatersrand, WITS 2050, South Africa Current address: German Remote Sensing Data Center (DFD), German Aerospace Center (DLR), P.O. Box 1116, D-82234, Wessling, Germany e-mail: andreas.hirner@dlr.de

\section{R.A. Armstrong}

Research School for Earth Sciences, The Australian National University, Canberra, ACT 0200, Australia e-mail: richard.armstrong@prise.anu.edu.au

\section{C.R. Anhaeusser}

Economic Geology Research Institute, School of Geosciences, University of the Witwatersrand, Private Bag 3, WITS 2050, South Africa e-mail: carl.anhaeusser@wits.ac.za

(C) 2008 March Geological Society of South Africa

\begin{abstract}
The Madibe greenstone belt is the easternmost belt of the northern Kraaipan terrane, located in the Kimberley Block of the Kaapvaal Craton. It comprises a mature Middle to Late Archaean volcanic island arc succession that was welded onto the evolving western margin of the Kaapvaal Shield. The lithologies strike in a north-south direction and represent an assemblage of metamorphosed and strongly deformed volcanic and minor sedimentary rocks, now represented by phyllites, quartz-sericite schists, quartz-chlorite schists, amphibolites, talc-carbonate schists and banded iron formations.

We report a SHRIMP U-Pb age of 3082.5 $\pm 5.9 \mathrm{Ma}$ for an intermediate metavolcanic rock. Ages of zircon grains within a volcanosedimentary rock define ages around 3.43, 3.18 and, $\sim 3.09 \mathrm{Ga}$ and are as young as $\sim 3.04 \mathrm{Ga}$, suggesting the presence of older, mature continental crust. Age relationships of rocks from the Madibe greenstone belt and the Murchison greenstone belt suggest that the Kaapvaal Shield apparently experienced an episode of rapid crustal growth at around $3090 \mathrm{Ma}$ along both the northern and western margins.
\end{abstract}

\section{Introduction}

The Madibe greenstone belt represents the easternmost belt of the Kraaipan granite-greenstone terrane (Figure 1) and is located in the Kimberley Block in the west-central part of the Kaapvaal Craton (Schmitz et al., 2004). Greenstone lithologies in the Kraaipan terrane are generally poorly exposed, being overlain by Cenozoic sand and calcrete of the Kalahari Group. Consequently, little is known about the detailed geology of this area and attempts to interpret the stratigraphy have been controversial. Until relatively recently the geochronology of the area has been largely unknown. This study presents new geochronological data for two samples from the main successions of the Madibe greenstone belt in order to shed some light on the processes that affected the evolution of the western part of the Kaapvaal Craton.

\section{Regional Geology}

The Kraaipan granite-greenstone terrane, located about $350 \mathrm{~km}$ west of Johannesburg, extends from approximately $50 \mathrm{~km}$ north of the Botswana border southwards towards Vryburg and Delareyville (Figure 1). The Kraaipan Group (SACS, 1980) of rocks is exposed in three, narrow, north-northwesterly trending greenstone belts that are surrounded by a variety of intrusive granitoid rocks (Anhaeusser, 1991; Zimmermann, 1994; Anhaeusser and Walraven, 1999; Hirner, 2000; Poujol et al., 2002; Brandl et al., 2006; Robb et al., 2006).

To the east, the Madibe belt (or Eastern Belt) is $4 \mathrm{~km}$-wide, north-northeast trending and is located about $10 \mathrm{~km}$ south-southwest of Mmabatho. It can be traced along strike for a distance of $40 \mathrm{~km}$ (Figure 1). The $10 \mathrm{~km}$-wide Kraaipan belt (or Central Belt) is located $40 \mathrm{~km}$ to the west of the Madibe belt. This belt extends over a distance of $90 \mathrm{~km}$ in a northnorthwest direction, continuing for an additional $35 \mathrm{~km}$ in a general northerly direction. The rocks in the Kraaipan belt are steeply dipping and display numerous large-scale internal fold structures. Finally, to the west, the $10 \mathrm{~km}$-wide, north-northwesterly-trending Stella belt 


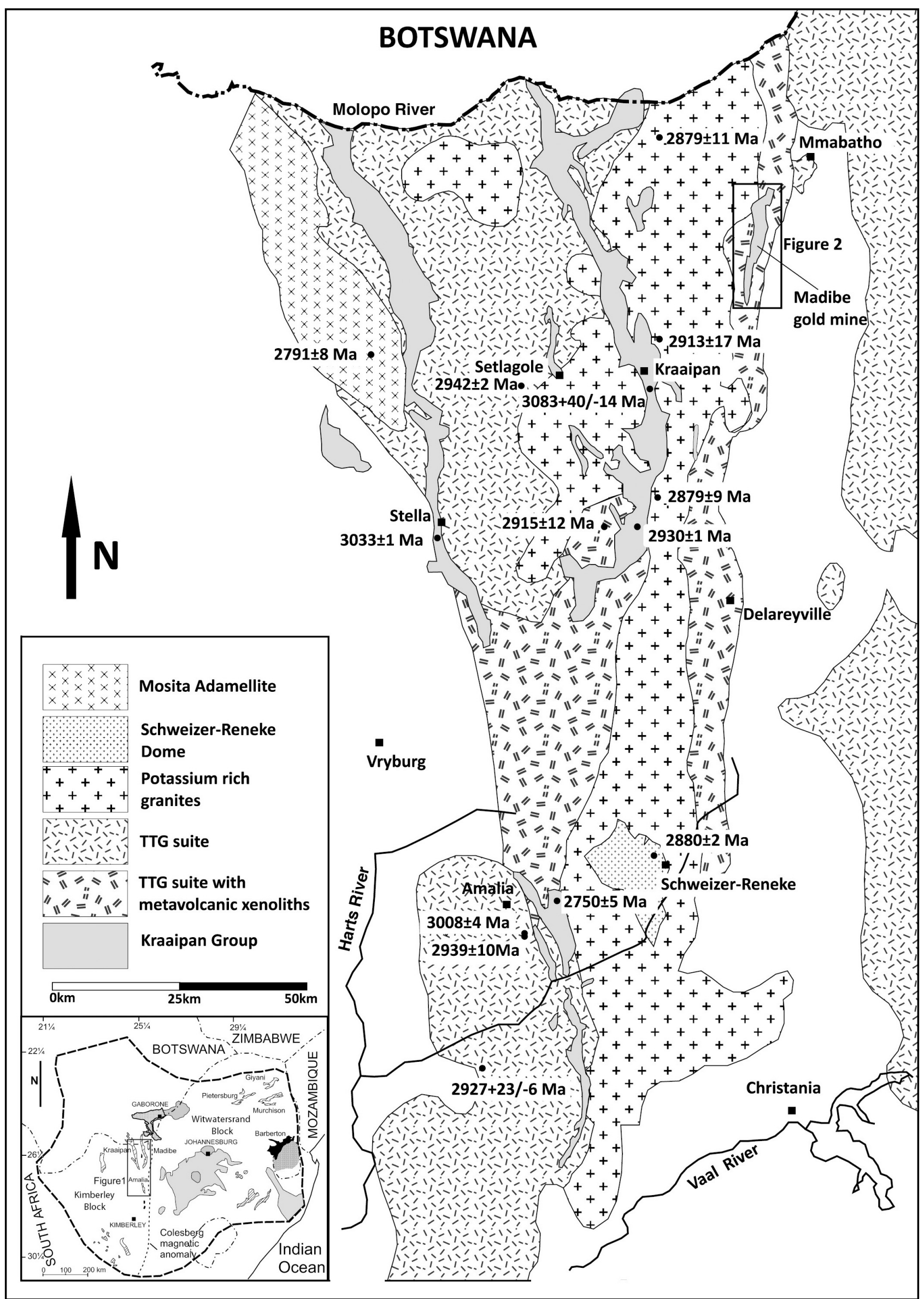

Figure 1. Geology of the Kraaipan and Amalia Terranes. Modified from Anhaeusser and Walraven (1999) and Mowatt (1997). See text for source references regarding ages. 
(or Western Belt) is located $50 \mathrm{~km}$ west of the Central Belt, and has a strike length close to $100 \mathrm{~km}$ (Figure 1).

Approximately $60 \mathrm{~km}$ south of the Kraaipan terrane lies the $55 \mathrm{~km}$-long, $5 \mathrm{~km}$-wide Amalia greenstone belt, which strikes in the same direction as the Kraaipan belts (Figure 1). Poujol et al. (2005) reported an age of 2750.1 $\pm 4.6 \mathrm{Ma}$ from supracrustal rocks of the Amalia greenstone belt.

The greenstones of the Kraaipan granite-greenstone terrane crop out in northerly-trending belts that are crosscut by anastomosing shear zones. The rocks in the western and central parts of the Kraaipan terrane are dominated by two volcano-clastic assemblages. The first comprises a homogeneous succession of mafic volcanic rocks with thin beds of chemical precipitates; clastic sedimentary rocks and pyroclastic units represent only a minor constituent. The second assemblage consists of alternating thick units of banded iron formation (BIF) and thin units of mafic volcanic rocks. More abundant pyroclastic rocks, epiclastic sedimentary rocks, rhyolitic tuffs and mafic intrusions are also present (Hirner, 2000).

A study by Anhaeusser and Walraven (1999) classified the granitic rocks in the Kraaipan terrane into three groups: (1) rocks of the trondhjemite-tonalitegranodiorite (TTG) suite; (2) K-rich alkali granites, syenogranites and granodiorites; and (3) coarse-grained, pinkish, K-rich adamellites (the latter also referred to as the Mosita adamellite) occurring to the west of the Stella belt (Figure 1). Subsequent investigations by Poujol et al. (2002) provided support for the multi-episodic granitoid emplacement during the evolution of the Kraaipan granite-greenstone terrane.

The northerly-trending Colesberg magnetic anomaly (Figure 1, inset) separates the Witwatersrand and Kimberley Blocks (Schmitz et al., 2004). The Colesberg anomaly is also present as suboutcrops around the Vredefort Dome impact structure. Corner et al. (1990) interpreted the Colesberg magnetic anomaly as a midcrustal layer that has been upwarped along the westcentral sector of the Kaapvaal shield and which re-occurs in the Vredefort Dome (see also Drennan et al., 1990).

\section{Previous geochronological work}

$\mathrm{Pb}-\mathrm{Pb}$ evaporation ages for the tonalitic-trondhjemitic gneisses (TTGs) range between $\sim 3.16$ to $\sim 3.07 \mathrm{Ga}$, whereas the K-rich granitoids yielded ages around $\sim 2.89$ to $2.85 \mathrm{Ga}$ (Anhaeusser and Walraven, 1999). Recent TIMS and SHRIMP U-Pb data demonstrate episodic granitoid emplacement events that occurred over a time span of approximately $250 \mathrm{Ma}$ (Poujol et al., 2002). These data show that the oldest granitoid rocks so far recognised crystallized at $3008 \pm 4 \mathrm{Ma}$ (Poujol et al., 2002) and are now represented by biotite-trondhjemite gneisses best exposed southwest of Amalia (Figure 1). Homogeneous leuco-trondhjemite dykes intruding these gneisses yielded an age of $2939 \pm 10 \mathrm{Ma}$ (Poujol et al., 2002). Further to the northeast (not shown on figure 1), south of the town of Kukong in Botswana, another granitic rock was dated at $2928 \pm 4 \mathrm{Ma}$ (Kamo et al., 1995). A further two granodiorite samples from northeast and southwest of Kraaipan (Figure 1) are dated at 2913 $\pm 17 \mathrm{Ma}$ and $2915 \pm 12 \mathrm{Ma}$, respectively (Poujol et al., 2002). A further two granodiorite samples, one south of Kraaipan and the other near the Botswana border have been dated at $2879 \pm 9 \mathrm{Ma}$ and $2879 \pm 11 \mathrm{Ma}$ (Poujol et al., 2002). The youngest granitoid body recognized thus far, the Mosita adamellite, yielded an age of $2791 \pm$ 8 Ma (Poujol et al., 2002). This age is identical, within error, with the age of $2784.5 \pm 4$ Ma found for an undeformed granite in southeastern Botswana (Mapeo et al., 2004). North of the Molopo River in Botswana (Figure 1), granitoid material recovered from boreholes have yielded ages of $2939 \pm 9 \mathrm{Ma}$ (biotite granite gneiss) and $2943 \pm 9 \mathrm{Ma}$ (pink granite) similar to those from the Kraaipan terrane (Mapeo et al., 2004, not shown on figure 1). In addition, a period of anorogenic magmatism is recorded by the emplacement of the Gaborone Granite Complex at $2781 \pm 2 \mathrm{Ma}$ (Grobler and Walraven, 1993).

Schmitz et al. (2004) reported an U-Pb age of 3033 $\pm 1 \mathrm{Ma}$ for an anorthositic gabbro of the Stella Complex, which is intrusive into the lower Kraaipan Group rocks north of Stella. In the central Kraaipan, Schmitz et al. (2004) reported a U-Pb age of $2930 \pm 1$ Ma for a rhyolitic tuff sampled within the Khunwana Chert Formation. These various dates have been interpreted as the crystallization ages of the rock types cited.

\section{Madibe greenstone belt}

Mapping, trenching, drilling and analysis of aeromagnetic and radiometric data have accurately delineated the extent of the Madibe greenstone belt and the lithological assemblages within it (Figure 2). The exposed part of the belt, bounded by faults and shear zones, is $3 \mathrm{~km}$ wide and $16 \mathrm{~km}$ long, and is defined by a succession of northerly striking steeply dipping metavolcanic and metasedimentary rocks in the upper greenschist to lower amphibolite facies (Hirner, 2000, Figure 2). The eastern limit of the Madibe greenstone belt comprises strongly sheared and altered mafic to ultramafic schists. The Madibe belt is also enveloped by strongly sheared TTG granitoids (Anhaeusser and Walraven, 1999), which enclose numerous, elongated, large (up to $1 \mathrm{~km}$ long and $100 \mathrm{~m}$ wide) greenstone remnants. Late K-rich granitic bodies intrude both the greenstones and the TTG-suite (Figure 2).

The Madibe greenstone belt comprises three major lithological assemblages. These are: (1) the western succession; (2) the central succession; and (3) the eastern succession (Hirner, 2000). The rocks defining these successions are strongly deformed and the contacts between the different lithologies are often sheared. They are regarded as tectono-stratigraphic sequences that preserve the initial lithological associations (Hirner, 2000).

The western succession is up to $500 \mathrm{~m}$ wide and extends north-south over a distance of $10 \mathrm{~km}$. 


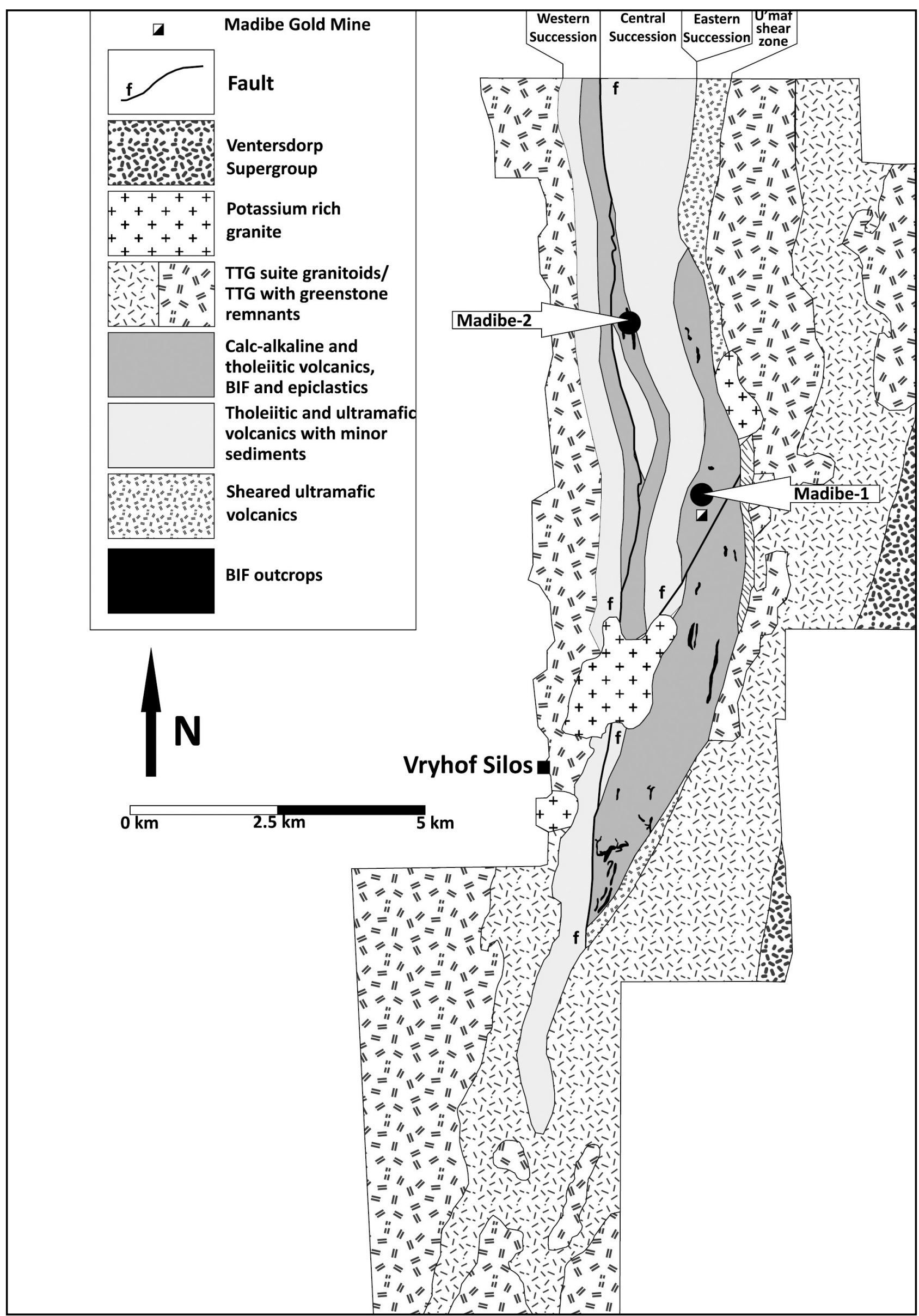

Figure 2. Geology of the Madibe greenstone belt. Interpretation based on mapping and geophysical observations (Hirner, 2000). 
It comprises mainly decimetre to metre thick units of oxide facies BIF, which occur intercalated with thick units of phyllites and quartz-sericite schists. Quartzchlorite schists, amphibolites, and thin, strongly deformed ultramafic schists are also present in minor amounts along the shear zones. This succession has no topographic expression and is almost invariably thinly covered by reddish soil containing abundant quartz vein material and BIF pebbles (Hirner, 2000).

The $1500 \mathrm{~m}$-wide central succession is poorly exposed and consists of thick (10- $100 \mathrm{~m})$, but extremely weathered, mafic to ultramafic extrusive and intrusive rocks, with thin intercalations of metatuffs and metasediments (Hirner, 2000).

The 1500 m-wide eastern succession has a strike length of more than $14 \mathrm{~km}$ and consists of relatively thick ( 1 to $10 \mathrm{~m}$ ) units of oxide facies BIF, intercalated with thick quartz-chlorite schists, phyllites and quartzsericite schists, subordinate amphibolites and ultramafic intrusions (Hirner, 2000). The northern part of the eastern succession is fairly uniform, but further to the south, two $300 \mathrm{~m}$-wide horizons, with a high percentage of BIF, envelope a 500 m-thick uniform succession of mafic extrusives. The eastern succession forms a gentle ridge to the north that forks into two flattopped ridges (BIF) separated by a depression (mafic material) in the southern part of the belt (Hirner, 2000).

The Madibe gold mine is situated on the eastern succession, close to the central part of the greenstone belt (Figures 1 and 2). The lithologies exposed in the underground workings comprise steeply westerly dipping quartz-chlorite schists and BIF. The ore body that plunges at $60^{\circ} \mathrm{N}$, is confined to a ductile shear zone that envelops a thick, northerly-striking unit of BIF. The shear zone is defined by quartz-chlorite shear bands and mineralization occurs in the hanging wall (west) and footwall (east) of the main BIF unit (Hirner, 2000). The mineralization process commenced during a period of brittle/ductile deformation and resulted in the replacement of the host rocks by a variety of ironbearing carbonates, chlorites, amphiboles and ore minerals. Three distinct mineralization events have been distinguished and linked to different periods of deformation and alteration (Hirner, 2000).

\section{Sample petrography}

Two felsic schist samples, one from the eastern succession and the other one from the western succession (Figure 2), were selected for zircon U-Pb dating. Sample Madibe-1, (Figure 2) comes from a borehole drilled by Shell (2559'49"S, 2532'10"E) and belongs to a sequence of quartz-sericite schist from the hanging wall of the ore body. The second sample (Madibe-2, Figure 2) was collected in an old trench (25'58'18's, 25'31'26"E) in the northern part of the western succession.

Sample Madibe-1 consists mainly of lower greenschist facies quartz-sericite schist, whereas sample Madibe-2 is an upper greenschist facies phyllite/ mylonite. The quartz-sericite schists (Madibe-1) are relatively coarse grained, well foliated, and have a beige to light- green colour. The matrix comprises small muscovite crystals together with minor chlorite that encompasses abundant, millimetre-sized, elongated quartz and sigmoidal feldspar crystals and lenses. Small mineral variations in thin, laterally inconsistent lenses are dominated by muscovite, chlorite, quartz, or albite. Occasionally, small $(<1 \mathrm{~mm})$, beige, lath-shaped minerals (chloritoid) occur within muscovite-rich bands. Foliation is isoclinally folded. Long, thin and coarsegrained quartz lenses parallel to the foliation are common and are interpreted as early vein material.

The phyllites (Madibe-2) are characterized by thick muscovite-rich layers and thin lenses comprising quartz and albite. The rocks are either beige or grey and have a strong lustre. Foliation is prominent and isoclinal folds are difficult to detect. Small crystals of muscovite are associated with minor biotite, chlorite and rutile. Stretched and boudinaged quartz- and albite-rich lenses are surrounded by thin chlorite-rich bands. Larger albite porphyroclasts are often dismembered and arranged in trails comprising small sigmoidal-shaped albite crystals. Coarse-grained quartz lenses, subparallel to the foliation, are attributed to an early event of veining. Oxidation along cleavage planes and brittle fractures produce redstained streaks and patches parallel to the cleavage.

\section{Sample geochemistry}

$\mathrm{X}$-Ray fluorescence spectrometry (XRF) analyses were performed on a Phillips 1400 spectrometer in the Department of Geology at the University of the Witwatersrand. Major elements were determined using fused discs (total $\mathrm{Fe}$ expressed as $\mathrm{Fe}_{2} \mathrm{O}_{3}$ ), trace elements (Rb, Ba, Sr, Y, Zr, Nb, Co, Ni, Cu, Zn, V, Cr, Pb, As) were determined on pressed powder briquettes using standard XRF techniques. Both major and trace element data for six massive quartz-sericite schists and 3 phyllites are shown in Table 1.

\section{Weatbering and alteration}

Weathering usually results in the alteration of feldspars and the mobility of alkalis and LIL elements. In Table 1 are reported the CIA (Chemical Index of Alteration) values calculated after Nesbitt and Young (1982). Values lower than 55 are typical for fresh igneous rocks. Higher values indicate influence of weathering or earlier secondary alteration (hydrothermal or metasomatic). With the exception of sample MD07/01B, all the samples present CIA values higher than 55 . The weathering trend can also be graphically illustrated by a molecular $\left(\mathrm{CaO}+\mathrm{Na}_{2} \mathrm{O}\right)-\mathrm{Al}_{2} \mathrm{O}_{3}-\mathrm{K}_{2} \mathrm{O}$ diagram (Figure 3A) after Nesbitt and Young (1984). For comparison, average compositions of the volcanic rocks from the Superior Province (Grunsky et al., 1992) and of Archaean TTG, granite, felsic volcanic, andesite, greywacke, shale and sandstone (Condie, 1993) are reported. Although Sample Madibe-1 presents a CIA value of 64 , it plots very close to the field defined by the unaltered Superior 
Table 1. Whole rock major (weight. \%) and trace element (ppm) compositions of selected massive quartz-sericite schist (qss_m) and phyllite (phyll) samples. CIA values were calculated on the basis of molecular proportions of elements oxides (Nesbitt and Young, 1984). Samples for geochronology: Madibe- $1=$ MD11/01C and Madibe- $2=$ BZP $/ 02 B$.

\begin{tabular}{|c|c|c|c|c|c|c|c|c|c|}
\hline Sample & MD07/01B & MD09/04B & MD09/04C & MD11/01B & MD11/01C & MD09/04A & AZP/06A & BZP/02A & BZP/02B \\
\hline Type & qss_m & qss_m & qss_m & qss_m & qss_m & qss_m & phyll & phyll & phyll \\
\hline $\mathrm{SiO}_{2}$ & 50.55 & 66.68 & 64.02 & 54.44 & 59.16 & 57.83 & 62.36 & 70.29 & 69.31 \\
\hline $\mathrm{TiO}_{2}$ & 0.43 & 0.53 & 0.55 & 0.5 & 0.54 & 0.59 & 0.53 & 0.45 & 0.52 \\
\hline $\mathrm{Al}_{2} \mathrm{O}_{3}$ & 13.39 & 13.45 & 13.86 & 16.47 & 17 & 14.98 & 14.01 & 10.25 & 12.22 \\
\hline $\mathrm{Fe}_{2} \mathrm{O}_{3 \mathrm{t}}$ & 6.16 & 5.93 & 5.7 & 6.86 & 4.96 & 9.35 & 10.21 & 8.16 & 8.81 \\
\hline $\mathrm{MnO}$ & 0.15 & 0.09 & 0.09 & 0.13 & 0.1 & 0.08 & 0.03 & 0.07 & 0.15 \\
\hline $\mathrm{MgO}$ & 4.71 & 3.76 & 4.24 & 4.07 & 2.82 & 4.7 & 2.96 & 3.23 & 4 \\
\hline $\mathrm{CaO}$ & 9.21 & 1.61 & 2.09 & 6.83 & 5.55 & 2.02 & 0.33 & 0.38 & 0.3 \\
\hline $\mathrm{Na}_{2} \mathrm{O}$ & 2.6 & 3.19 & 2.53 & 1.62 & 2.71 & 1.9 & 0.98 & 0.62 & 0.51 \\
\hline $\mathrm{K}_{2} \mathrm{O}$ & 0.68 & 1.99 & 2.49 & 1.6 & 1.44 & 3.09 & 2.78 & 1.04 & 1.3 \\
\hline $\mathrm{P}_{2} \mathrm{O}_{5}$ & 0.17 & 0.11 & 0.12 & 0.2 & 0.19 & 0.11 & 0.08 & 0.11 & 0.11 \\
\hline LOI & 10.88 & 3.39 & 4.63 & 8.09 & 6.32 & 5.03 & 5.36 & 4.59 & 4.62 \\
\hline Total & 98.94 & 100.74 & 100.31 & 100.81 & 100.78 & 99.68 & 99.65 & 99.19 & 101.84 \\
\hline $\mathrm{Ba}$ & 136 & 425 & 480 & 308 & 377 & 653 & 2337 & 314 & 445 \\
\hline $\mathrm{Rb}$ & 21 & 55 & 72 & 36 & 39 & 89 & 11 & 40 & 53 \\
\hline $\mathrm{Sr}$ & 198 & 184 & 194 & 193 & 224 & 221 & 45 & 67 & 70 \\
\hline $\mathrm{Y}$ & 9 & 14 & 13 & 8 & 8 & 16 & 33 & 10 & 10 \\
\hline $\mathrm{Zr}$ & 117 & 128 & 132 & 99 & 106 & 130 & 168 & 102 & 100 \\
\hline $\mathrm{Nb}$ & 8 & 11 & 11 & 9 & 9 & 11 & 16 & 9 & 10 \\
\hline $\mathrm{Pb}$ & 16 & & 12 & & & 17 & 14 & & 19 \\
\hline $\mathrm{Zn}$ & 93 & 83 & 77 & 91 & 74 & 67 & 125 & 163 & 282 \\
\hline $\mathrm{Cu}$ & 2 & 15 & 8 & 9 & 8 & 8 & 73 & 48 & 27 \\
\hline $\mathrm{Ni}$ & 49 & 107 & 111 & 40 & 37 & 154 & 183 & 163 & 214 \\
\hline V & 84 & 81 & 78 & 108 & 91 & 104 & 123 & 101 & 103 \\
\hline $\mathrm{Cr}$ & 64 & 461 & 440 & 74 & 72 & 505 & 389 & 232 & 359 \\
\hline $\mathrm{Co}$ & & & 9 & & & 22 & 12 & 16 & 35 \\
\hline As & & & 21 & & 27 & 31 & 178 & & \\
\hline CIA & 52 & 66 & 66 & 62 & 64 & 68 & 77 & 83 & 85 \\
\hline
\end{tabular}

Province calc-alkaline volcanics, whereas sample Madibe-2 (CIA $=85)$ plots very close to the $\mathrm{Al}_{2} \mathrm{O}_{3}$ apex.

Besides weathering, deformation and metamorphism can change the chemical composition of a rock, especially during mylonitization. Solution and removal of $\mathrm{Si}$ and the alkali elements are possible processes, although enrichment of $\mathrm{Si}$ along with removal of the alkali elements is also reported (Tobish et al., 1991). This would mean that a change in chemical composition during metamorphism could lead to a decrease of alkali elements relative to aluminium and, therefore, the effects should lead to higher CIA values just as weathering does.

\section{Nature of the sample protoliths}

Sample Madibe-1 has a composition compatible with igneous rocks in the Hughes (1973) diagram (Figure 3B) and shows a slightly peraluminous composition in the Maniar and Piccoli (1989) diagram (Figure 3C). This sample protolith may therefore be considered as magmatic. This is supported by the $\mathrm{P}_{2} \mathrm{O}_{5} / \mathrm{TiO}_{2}$ versus $\mathrm{MgO} / \mathrm{CaO}$ diagram (Werner, 1987; Figure 3D) where sample Madibe- 1 plots in the magmatic field, although this diagram should be used with caution and in conjunction with other parameters such as petrological criteria (Passchier et al., 1990).

In an AFM diagram (Irvine and Baragar, 1971; Figure 3F), all the massive quartz sericite schists fall within the calc-alkaline field. In both the TAS diagram (Middlemost, 1994; Figure 3E) and the $\mathrm{Zr} / \mathrm{Ti}$ vs. $\mathrm{Nb} / \mathrm{Y}$ diagram using immobile elements (Winchester and Floyd, 1977; Figure 3G), the massive quartz-sericite schists define a trend from andesitic to dacitic compositions. This is confirmed in a molecular normative An-Ab-Or ternary diagram (Barker, 1979; not shown), where sample Madibe- 1 falls into the tonalitic field.

To our knowledge, there is no diagram to argue conclusively either for or against a magmatic origin for this sample. Indeed, the breakdown of a single volcanic rock will give a sedimentary rock with identical chemical properties, except perhaps for the mobile elements. Diagrams using such mobile elements do not show any particular anomalies in the case of Madibe- 1 . Furthermore, if the massive quartz-sericite schists were sedimentary rocks, one could expect that they were derived from several magmatic source types. 

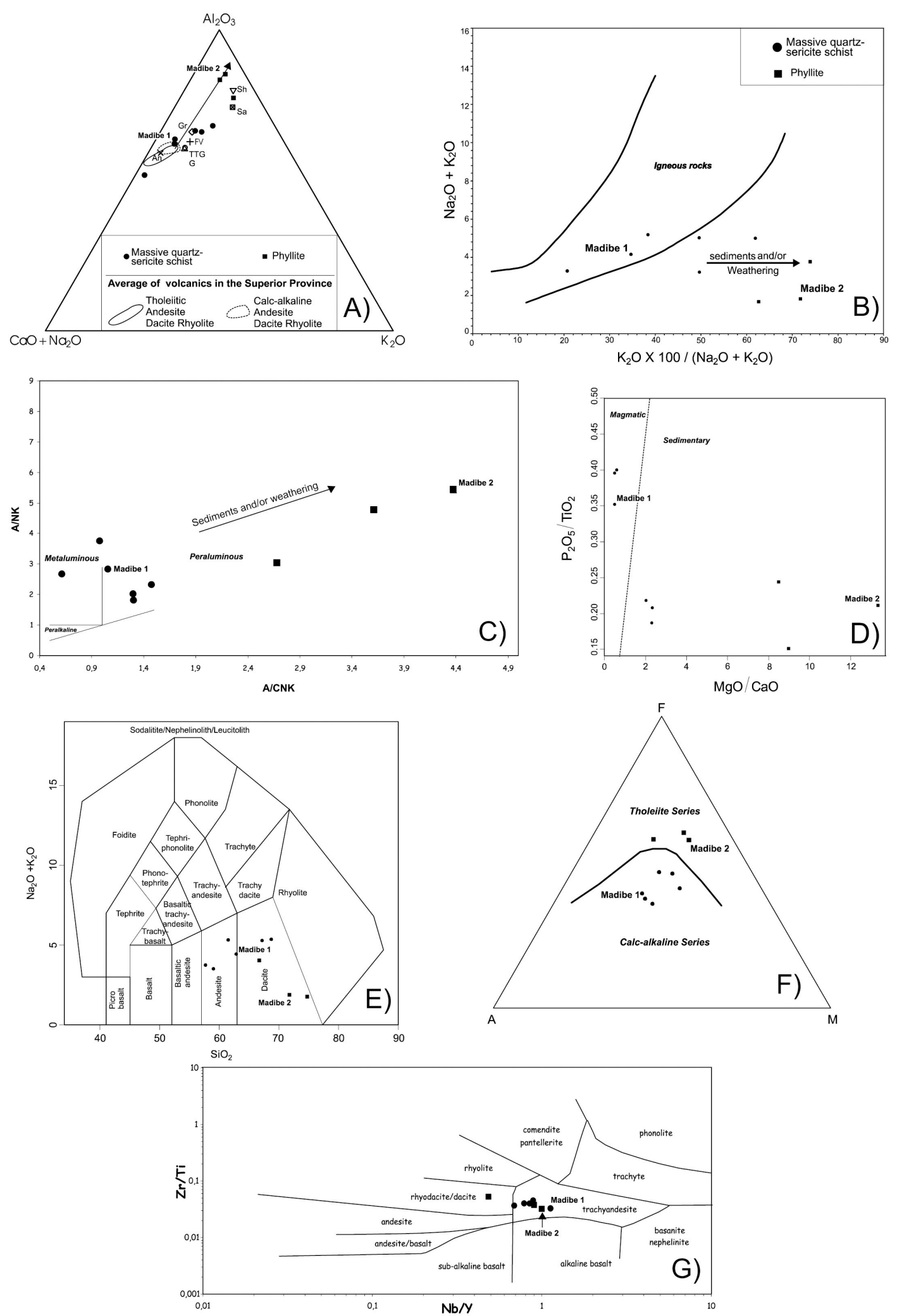

Figure 3. All diagrams were made using GCDKit (Janousek et al., 2006). A) Ternary diagram of molecular $\left(\mathrm{CaO}+\mathrm{Na}_{2} \mathrm{O}\right)-\mathrm{Al}_{2} \mathrm{O}_{3}-\mathrm{K}_{2} \mathrm{O}$. $\mathrm{Arrow}^{-}$ shows typical weathering trend according to Nesbitt and Young (1984). TTG = TTG, G = granite, FV = felsic volcanic, An = andesite, $\mathrm{Gr}=$ greywackes, $\mathrm{Sh}=$ shales and $\mathrm{Sa}=$ sandstone. Average Archean compositions after Condie (1993); B) Whole-rock composition in a $\left(\mathrm{Na}_{2} \mathrm{O}+\mathrm{K}_{2} \mathrm{O}\right)$ versus $\mathrm{K}_{2} \mathrm{O} /\left(\mathrm{K}_{2} \mathrm{O}+\mathrm{Na}_{2} \mathrm{O}\right)$ (weight \%) diagram (Hughes, 1973); C) Whole-rock composition in a A/ $\mathrm{NK}\left(\mathrm{Al}_{2} \mathrm{O}_{3} /\left(\mathrm{Na}_{2} \mathrm{O}+\mathrm{K}_{2} \mathrm{O}\right)\right.$ ) versus A/CNK $\left(\mathrm{Al}_{2} \mathrm{O}_{3} /\left(\mathrm{CaO}+\mathrm{Na}_{2} \mathrm{O}+\mathrm{K}_{2} \mathrm{O}\right)\right.$ ) diagram (Maniar and Piccoli, 1989); D) Major element discrimination $\mathrm{P}_{2} \mathrm{O}_{5} / \mathrm{TiO}_{2}$ versus $\mathrm{MgO} / \mathrm{CaO}$ diagram (Werner, 1987); E) Whole-rock composition in a $\left(\mathrm{Na}_{2} \mathrm{O}+\mathrm{K}_{2} \mathrm{O}\right.$ ) versus $\mathrm{SiO}_{2}$ (weight \%) TAS diagram (Middlemost, 1994); F) Ternary AFM diagram (Irvine and Baragar, 1971) and G) Whole-rock Zr/Ti versus Nb/Y diagram (Winchester and Floyd, 1977). 


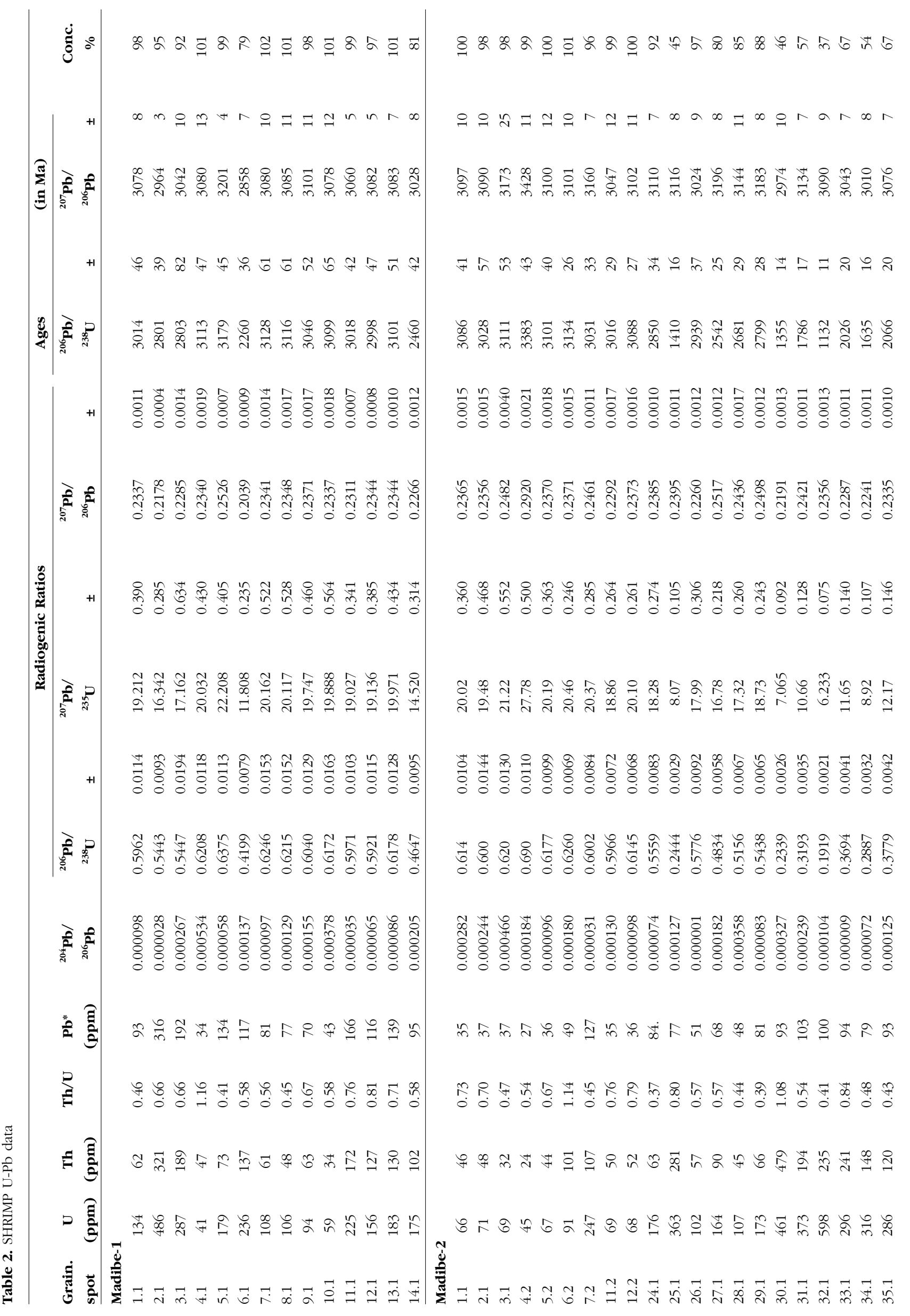


This would certainly lead to a scattering of the data in most of the diagrams. On the contrary, the data for these massive quartz-sericite schists show typical calc-alkaline trends, with all the different diagrams used in this study pointing towards a magmatic origin. Consequently, Madibe- 1 is interpreted as a calc-alkaline andesite/dacite extrusive, although a sedimentary origin cannot be completely ruled out.

Sample Madibe-2, as shown in Figure 3A, presents characteristics of either a weathered or metasomatised rock. This is confirmed by the Hughes diagram (Figure $3 \mathrm{~B})$, in which it plots outside the igneous rocks field. In the Maniar and Piccoli (1989) diagram (Figure 3C), sample Madibe-2 plots completely to the right, far into the peraluminous field. This means that this sample is too K-rich and too peraluminous compared with igneous rock. Consequently, sample Madibe-2 is either a highly weathered/metasomatised igneous rock or a sedimentary rock derived from the erosion of a magmatic rock, or a combination of both. This ambiguous nature of the protolith is confirmed by the Werner's (1987) diagram, in which sample Madibe-2 falls outside the igneous field (Figure 3D).

In the AFM (Figure 3F) diagram, sample Madibe-2 plots in the tholeitic field, while the TAS diagram (Figure 3E) indicates a dacitic nature for Madibe-2. Because of the potential highly weathered/ metasomatised nature of Madibe-2, such diagrams using mobile elements should be used with caution. The Winchester and Floyd (1977) diagram (Figure 3G), which uses immobile elements, plots sample Madibe-2 very close to Madibe-1, in the trachyandesite field. In this diagram, both massive quartz-sericite schists and phyllites/mylonites plot along an apparent classical trend of magmatic differentiation from trachyandesitic to rhyodacitic/dacitic compositions. In the light of these observations, a volcano-sedimentary origin is proposed for the Madibe-2 protolith, although a purely sedimentary origin can not be ruled out.

\section{Geochronology \\ Analytical techniques}

A full description of the analytical techniques used can be found in Poujol et al. (2002). Analyses were performed at the Research School for Earth Sciences at the Australian National University, Canberra on SHRIMP II. All errors quoted in Table 2 are listed at $1 \sigma$, but where data are combined for regression analysis or weighted mean age, the final result is quoted within the 95\% confidence limits. All the geochronological statistical assessments were performed using the Isoplot/Ex 3.0 program of Ludwig (2000).

\section{Results}

Very few zircon grains were extracted from sample Madibe- 1 . They were generally prismatic and pinkish in colour. Cathodoluminescence imaging of these zircon grains shows that they are mostly compositionally zoned and free of potential cores and overgrowths (Figure 4). Most grains show broad and faint zoning. Fourteen grain spots from 14 zircon grains were analysed and the data are reported in Table 2. A group of eight concordant grains (Figure $5 \mathrm{~A}$ ) combine to a weighted ${ }^{207} \mathrm{~Pb} /{ }^{206} \mathrm{~Pb}$ mean of $3082.5 \pm 5.9 \mathrm{Ma}$ (M.S.W.D. 0.48). This date is confirmed by a TuffZirc Age (calculated using Isoplot/ Ex 3.0 as defined in Ludwig and Mundil, 2002) of 3100 $+28 /-86 \mathrm{Ma}$. The Th/U ratios for these 8 grains vary slightly from 0.45 to 0.81 (1.16 for grain 4.1). Similar variation for Archaean volcanic rocks is not uncommon (see for example Blake et al., 2004). Another concordant grain (11.1) gives a ${ }^{207} \mathrm{~Pb} /{ }^{206} \mathrm{~Pb}$ date of $3060 \pm 5 \mathrm{Ma}$. This grain, combined with the previous eight zircon

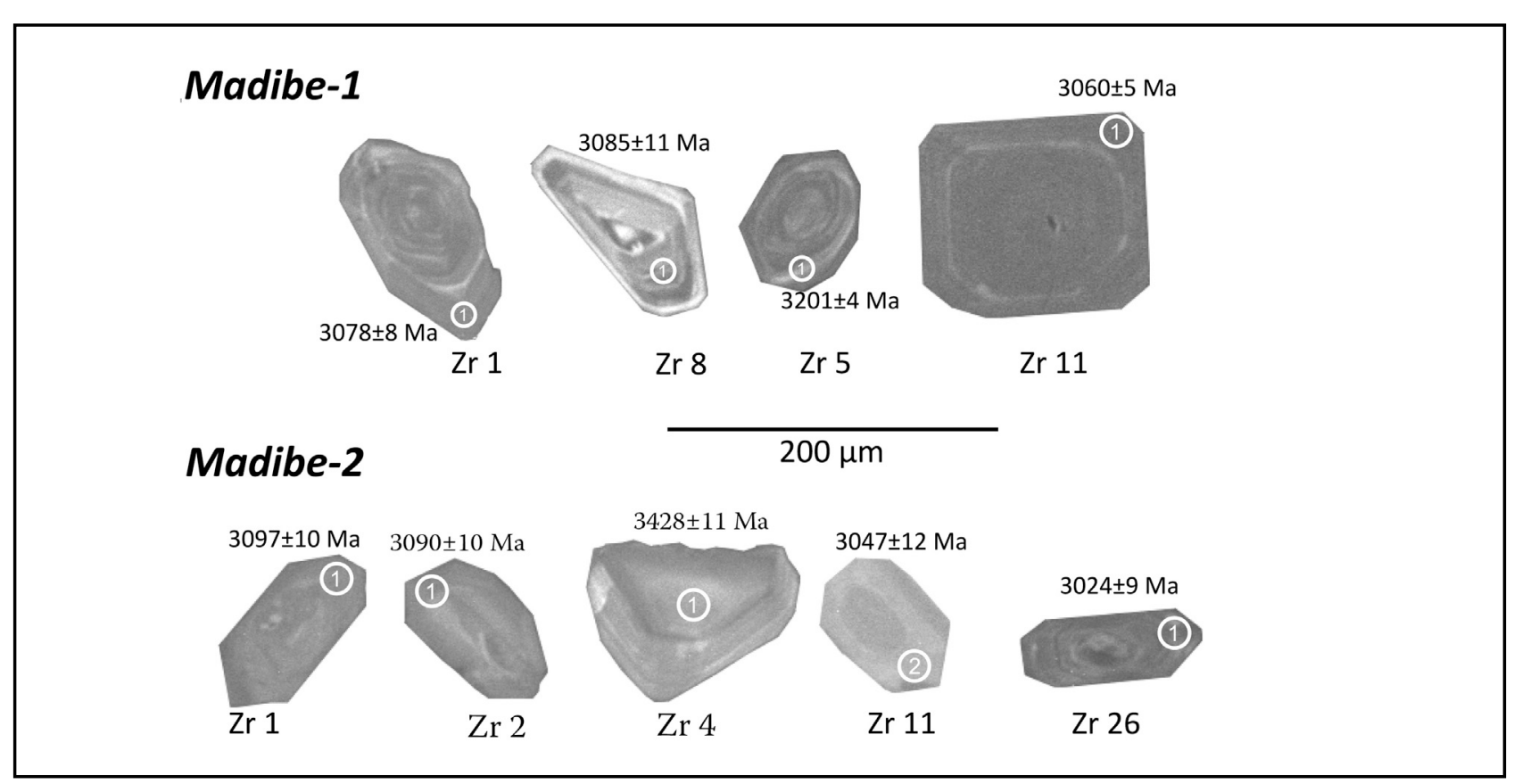

Figure 4. Cathodoluminescence photographs showing internal structure of some zircons from samples Madibe 1 and 2. 


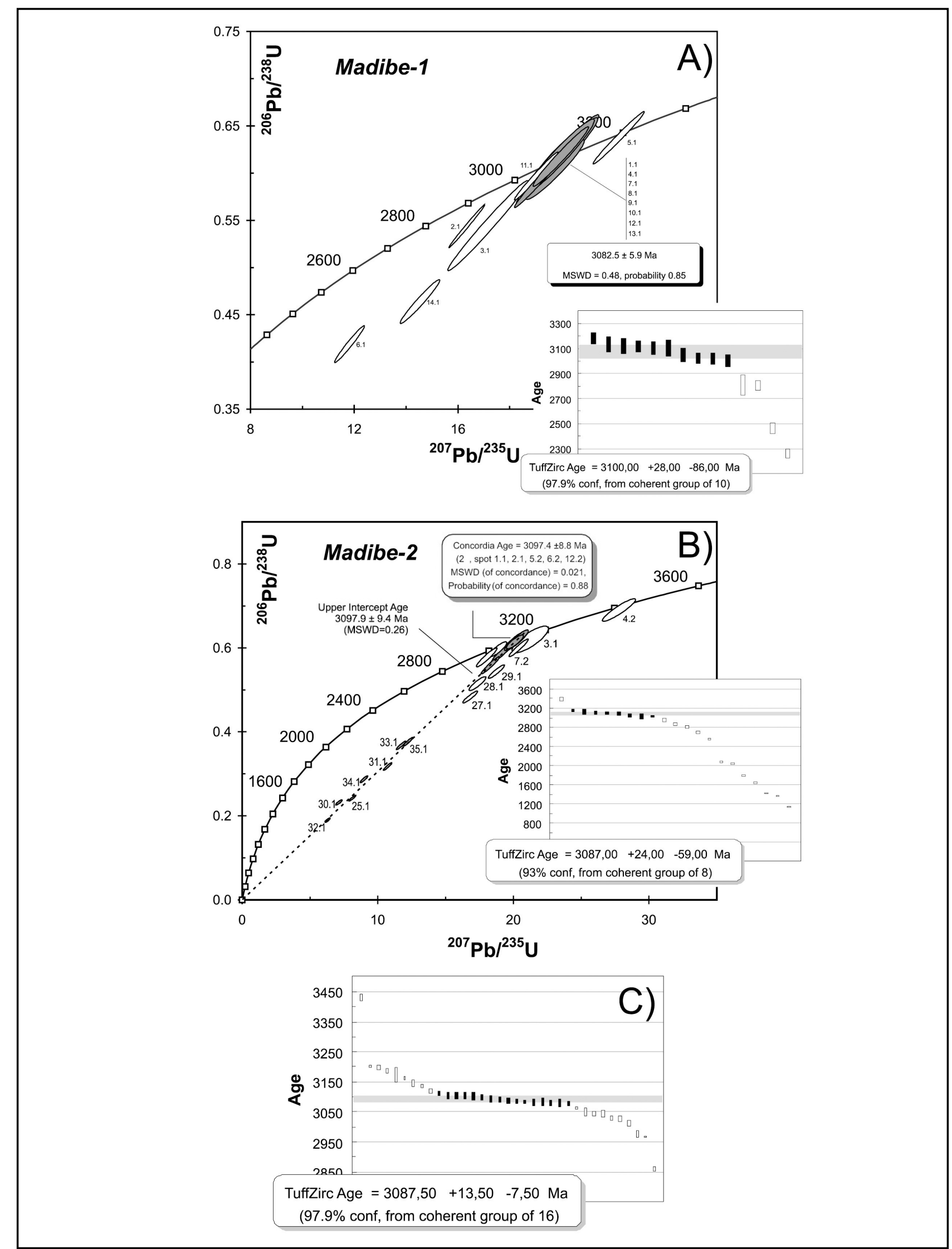

Figure 5. (A) U-Pb SHRIMP concordia diagram and TuffZirc Age diagram (Ludwig and Mundil, 2002) for sample Madibe-1. Only the shaded-ellipses have been used for the weighted-mean calculation. All data-point error ellipses and listed ages are at $95 \%$ confidence; (B) U-Pb SHRIMP concordia diagram and TuffZirc Age diagram for sample Madibe-2. Dashed-line represents the discordia age calculated for the shaded ellipses. All data-point error ellipses and listed ages are at 95\% confidence and (C) Combined TuffZirc Age diagram for samples Madibe-1 and Madibe-2. 
grains, yields an upper intercept date of $3080 \pm 6 \mathrm{Ma}$. Another grain (5.1, Table 1) is concordant with a ${ }^{207} \mathrm{~Pb} /{ }^{206} \mathrm{~Pb}$ date of $3201 \pm 4 \mathrm{Ma}$. The four remaining grains $(2.1,3.1,14.1$ and 6.1$)$ present different degrees of discordance and their positions could be attributed to complex Pb-loss behavior.

Very few zircon grains were recovered from sample Madibe-2. Zircon grains were prismatic and pink in colour with different degrees of metamictization. The absence of rounded grains could indicate either a magmatic origin or proximal source(s) for these zircon grains. Cathodoluminescence imagery (Figure 4) shows that most of the zircon grains, with few exceptions, present broad and faint zoning. Twenty-one spots from 21 grains were analysed (Table 2). Plotted on a Concordia diagram (Figure 5B), they define a wide range of ages. A group of five concordant grains combine to a Concordia age (Ludwig, 1998) of 3097.4 $\pm 8.8 \mathrm{Ma}(\mathrm{MSWD}=0.02)$. These five concordant grains, together with grain 24.1 define an identical upper intercept date of $3097.9 \pm 9.4 \mathrm{Ma} \quad(\mathrm{MSWD}=0.26$ ). This date is confirmed, within error, by the TuffZirc Age of $3087+24 /-59 \mathrm{Ma}$. A group of seven very discordant grains plot on, or very close to this discordia. The oldest concordant grain (4.2, Figure 5B) presents a ${ }^{207} \mathrm{~Pb} /{ }^{206} \mathrm{~Pb}$ date of $3428 \pm 11 \mathrm{Ma}$. A group of four grains (3.1, 7.2, 29.1 and 27.1 , Figure $5 \mathrm{~B}$ ) define a mean ${ }^{207} \mathrm{~Pb} /{ }^{206} \mathrm{~Pb}$ date of $3178 \pm 28 \mathrm{Ma}$. Two grains (11.2 and 26.1) in concordant to sub-concordant positions are defined by ${ }^{207} \mathrm{~Pb} /{ }^{206} \mathrm{~Pb}$ dates of $3047 \pm 12 \mathrm{Ma}$, and $3024 \pm 9 \mathrm{Ma}$, respectively.

\section{Discussion and conclusions Madibe greenstone belt}

The relatively homogeneous age population found for sample Madibe-1 agrees with a magmatic extrusive origin. Consequently, in the light of the data shown in Figure $5 \mathrm{~A}$, the date of $3082.5 \pm 5.9 \mathrm{Ma}$ found for the Madibe- 1 sample can be regarded as the emplacement age of this volcanic rock $(3080 \pm 6 \mathrm{Ma}$ if zircon 11 is included). Grain 5, with an age of $3201 \pm 4 \mathrm{Ma}$, can therefore be interpreted as a xenocryst.

The spread of ages found for sample Madibe-2 (Figure 5B) accords with either a sedimentary or a volcano-sedimentary origin for this rock and supports the geochemical data. If a volcano-sedimentary origin is considered, the date of $3047 \pm 12 \mathrm{Ma}$ found for the youngest most concordant grain (11.2) should be considered as the best estimate for the emplacement of this rock. In that case, the position in Figure $5 \mathrm{~B}$ for zircon 26, with a ${ }^{207} \mathrm{~Pb} /{ }^{206} \mathrm{~Pb}$ date of $3024 \pm 9 \mathrm{Ma}$, could be explained by a slight Pb-loss. All the older dates found $(3428 \pm 11 \mathrm{Ma}, 3178 \pm 28 \mathrm{Ma}$ and $3097.4 \pm$ $8.8 \mathrm{Ma})$ should be attributed to xenocrystic zircon grains.

Other dates, however, present some similarities with zircon grains extracted from sample Madibe-1, more particularly the group around $3090 \mathrm{Ma}$. When plotted together with data from sample Madibe-1 (Figure 5C), they define a well-constrained TuffZirc age of 3087.5 $+13.5 /-7.5$ Ma. This could represent evidence of the presence of volcanic (and/or plutonic) equivalents of Madibe-1 type material.

If sample Madibe- 2 is a metasedimentary rock, the date of $3047 \mathrm{Ma}$ represents the maximum age for the deposition of the precursor sediments.

In either case, it is interesting to note the presence of xenocrysts as old as $3428 \mathrm{Ma}$, with several others giving ${ }^{207} \mathrm{~Pb} /{ }^{206} \mathrm{~Pb}$ ages at $\sim 3.2$ and $3.18 \mathrm{Ga}$ and, if Madibe- 2 is a metasedimentary rock, ages as young as $\sim 3.09$ and $\sim 3.05 \mathrm{Ga}$. This implies that some older crustal material was present during to the volcanic activity in the Kimberley Block. This is confirmed by $\sim 3.3$ to $\sim 3.2 \mathrm{Ga}$ inherited zircon and $\mathrm{Nd}$ model ages found for some Kimberley gneisses further to the south (Schmitz et al., 2004) and by a xenocryst zircon from a felsic metavolcanics from the Kraaipan Group dated at 3157 Ma (Robb, 1991). Further to the north, in southeast Botswana, two zircon cores from biotite gneiss gave a weighted mean ${ }^{207} \mathrm{~Pb} /{ }^{206} \mathrm{~Pb}$ age of $3217 \pm 9 \mathrm{Ma}$ (Mapeo et al., 2004). Because of the wide range of ages, it could be argued that a block of mature basement had already formed by $\sim 3.2 \mathrm{Ga}$.

Recent data on the Johannesburg Dome (Poujol and Anhaeusser, 2001) have demonstrated the presence of TTG gneisses at $\sim 3.34$ and and $\sim 3.20 \mathrm{Ga}$ in the central part of the Kaapvaal Shield. These ages are in good agreement with some of the ages found for the xenocrysts within the Madibe samples, demonstrating that these two parts of the craton may have evolved during the same period.

As no age is currently available for the central succession of the Madibe greenstone belt, its origin and relationship with the western and eastern successions remain uncertain.

\section{Regional implications}

The $3082.5 \pm 5.9 \mathrm{Ma}$ age found for the Madibe- 1 sample is in a good agreement with an upper intercept age of $3083+40 /-14$ Ma found for some felsic metavolcanics from the Kraaipan central belt (L.J. Robb, unpublished. data quoted in Anhaeusser, 1991). A similar age of 3087 $\pm 21 \mathrm{Ma}$ was also found for the volcano-sedimentary rocks of the Weigel Formation from the Murchison greenstone belt, located in the northeastern sector of the Kaapvaal Craton (Poujol et al., 1996). Consequently, the Kaapvaal Shield appears to have experienced an episode of rapid crustal growth at $\sim 3.09 \mathrm{Ga}$, this being related to the accretion of several island arcs along an active continental margin located along the northern and western boundaries of the Kaapvaal Shield (Poujol et al., 2003).

\section{Acknowledgments}

We are very grateful to Steve McCourt and an anonymous reviewer who provided very helpful and insightful reviews of the original manuscript. Editorial handling by L. Ashwal is gratefully acknowledged. 


\section{References}

Anhaeusser, C.R. (1991). The Archaean Kraaipan Group of volcanosedimentary rocks and associated granites and gneisses of the southwestern Transvaal, Northwestern Cape Province and Bophuthatswana. Information Circular, Economic Geology Research Unit, University of the Witwatersrand, Johannesburg, South Africa, 244, 45pp.

Anhaeusser, C.R. and Walraven, F. (1999). Episodic granitoid emplacement in the western Kaapvaal Craton: evidence from the Archaean Kraaipan granite-greenstone terrane, South Africa. Journal of African Earth Sciences, 28, 289-309.

Barker, F. (1979). Trondhjemite: Definition, environment and hypothesis of origin: In: Barker F. (Editor), Trondhjemites, dacites and related rocks. Elsevier, Amsterdam, the Netherlands, 1-12.

Blake, T.S., Buick, R., Brown, S.J.A. and Barley, M.E. (2004). Geochronology of a Late Archaean flood basalt province in the Pilbara Craton, Australia: constraints on basin evolution, volcanic and sedimentary accumulation, and continental drift rates. Precambrian Research, 133, 143-173.

Brandl, G., Cloete, M. and Anhaeusser, C.R. (2006). Archaean greenstone belts. In: M.R. Johnson, C.R. Anhaeusser, and R.J. Thomas, (Editors). The Geology of South Africa. Geological Society of South Africa/Council for Geoscience, 9-56.

Condie, K.C. (1993). Chemical composition and evolution of the upper continental crust: Contrasting results from surface samples and shales. Chemical Geology, 104, 1-37.

Corner, B., Durrheim, R.J. and Nicolaysen, L.O. (1990). Relationship between the Vredefort structure and the Witwatersrand Basin within the tectonic framework of the Kaapvaal Craton as interpreted from regional gravity and aeromagnetic data. Tectonophysics, 171, 49-61.

Drennan, G.R., Robb, L.J., Meyer, F.M., Armstrong, R.A. and de Bruiyn, H. (1990). The nature of the Archaean basement in the hinterland of the Witwatersrand Basin: II. a crustal profile west of the Welkom Goldfield and comparisons with the Vredefort crustal profile. South African Journal of Geology, 93, 41-53.

Grobler, D.F. and Walraven, F. (1993). Geochronology of Gaborone Granite Complex extensions in the area north of Mafikeng, South Africa. Chemical Geology, 105, 319-337.

Grunsky, E.C., Easton, R.M., Thurston, P.C., Jensen, L.S. (1992). Characterization and statistical classification of Archaean volcanic rocks of the Superior Province using major element geochemistry. In: J.E. Glover and S.E. Ho, (Editors), Proceedings Volume for the 3rd International Archaean Symposium, Geology Key Centre and University Extension, the University of Western Australia; Publication, 22, 17-37.

Hughes, C.J. (1973). Spilites, keratophyres, and the igneous spectrum. Geological Magazine, 109, 513-527.

Hirner, A.J. (2000). Geology and gold mineralization in the Madibe Greenstone Belt, Kraaipan Terrain, Kaapvaal Craton. Unpublished PhD thesis, University of the Witwatersrand, Johannesburg, South Africa, 340pp.

Irvine, T.N. and Baragar, W.R.A. (1971). A guide to the chemical classification of the common volcanic rocks. Canadian Journal of Earth Sciences, 8, 523-548.

Janousek, V., Farrow, C.M. and Erban, V. (2006). Interpretation of whole-rock geochemical data in igneous geochemistry: introducing Geochemical Data Toolkit (GCDkit). Journal of Petrology, 47, 1255-1259.

Kamo, S.L., Key, R.M. and Daniels, L.R.M. (1995). New evidence for Neoarchaean, hydrothermally altered granites in south-central Botswana. Journal of the Geological Society, 152, 747-750.

Ludwig, K.R. (1998). On the treatment of concordant uranium-lead ages. Geochimica et Cosmochimica Acta, 62, 665-676.

Ludwig, K.R. (2000). Isoplot/Ex: a geochronological toolkit for Microsoft Excel. Bekerley Geochronology Center Special Publication, 1a, Bekerley, United States of America, $54 \mathrm{pp}$

Ludwig, K.R., and Mundil, R., 2002, Extracting reliable U-Pb ages and errors from complex populations of zircons from Phanerozoic tuffs: Geochimica et Cosmochimica Acta, v. 66, p. A463.

Maniar, P.D. and Piccoli, P.M. (1989). Tectonic discrimination of granitoids. Geological Society of America Bulletin, 101, 635-643.

Mapeo, R.B.M., Armstrong, R.A., Kampunzu, A.B. and Ramokate, L.V. (2004). SHRIMP U-Pb zircon ages of granitoids from the Western Domain of the Kaapvaal Craton, southeastern Botswana: implications for crustal evolution. South African Journal of Geology, 107, 159-172.

Middlemost, E.A.K. (1994). Naming materials in the magma/igneous rock system. Earth-Science Reviews, 37, 215-224.

Mowatt, G.J. (1997). Kalahari Goldridge Mining Company. Annual Report 1997, Kalahari Goldridge Mining Company, 44pp.

Nesbitt, H.W. and Young, G.M. (1982). Early Proterozoic climates and plate motions inferred from major element chemistry of lutites. Nature, 299, 715-717

Nesbitt, H.W. and Young, G.M. (1984). Prediction of some weathering trends of plutonic and volcanic rocks based on thermodynamic and kinetic considerations. Geochimica et Cosmochimica Acta, 48, 1523-1534.

Passchier, C.W., Myers, J.S. and Kröner, A. (1990). Field geology of highgrade gneiss terrains. Springer-Verlag, Germany, $150 \mathrm{pp}$

Poujol, M. and Anhaeusser, C.R. (2001). The Johannesburg Dome, South Africa: new single zircon U-Pb isotopic evidence for early Archaean granite-greenstone development within the central Kaapvaal Craton. Precambrian Research, 108, 139-157.

Poujol, M., Robb, L.J., Respaut, J.P. and Anhaeusser, C.R. (1996). 3.07-2.97 Ga greenstone belt formation in the north-eastern Kaapvaal Craton: implications for the origin of the Witwatersrand Basin. Economic Geology, 91, 1455-1461.

Poujol, M., Anhaeusser, C.R. and Armstrong, R.A. (2002). Episodic granitoid emplacement in the Archaean Amalia-Kraaipan terrane, South Africa: confirmation from single zircon U-Pb geochronology. Journal of African Earth Sciences, 35, 147-161.

Poujol, M., Robb, L.J., Anhaeusser, C.R. and Gericke, B. (2003). A review of the geochronological constraints on the evolution of the Kaapvaal Craton, South Africa. Precambrian Research, 127, 181-213.

Poujol, M., Kiefer, R., Robb, L.J., Anhaeusser, C.R. and Armstrong, R.A. (2005). New U-Pb data on zircons from the Amalia greenstone belt southern Africa: insights into the Neoarchaean evolution of the Kaapvaal Craton. South African Journal of Geology, 108, 317-332.

Robb, L.J. (1991). U-Pb determinations-felsic volcanics, Kraaipan Group. In:Anhaeusser, C.R., 1991, The Archaean Kraaipan Group of volcanosedimentary rocks and associated granites and gneisses of the southwestern Transvaal, Northwestern Cape Province and Bophuthatswana. Information Circular, Economic Geology Research Unit, University of the Witwatersrand, Johannesburg, South Africa, 244. 28-30.

Robb, L.J., Brandl, G., Anhaeusser, C.R. and Poujol, M. (2006). Archaean granitoid intrusions of the Kaapvaal Craton. In: M.R. Johnson, C.R. Anhaeusser and R.J. Thomas (Editors). The Geology of South Africa Geological Society of South Africa/Council for Geoscience, 57-94pp.

South African Committee for Stratigraphy (SACS), 1980. Stratigraphy of South Africa. Part 1. (Compiler, L. E. Kent). Lithostratigraphy of the Republic of South Africa, South West Africa/Namibia, and the Republics of Bophuthatswana, Transkei and Venda. Handbook, Geological Survey of South Africa, 8, 690pp.

Schmitz, M.D., Bowring, S.A., de Wit, M.J. and Gartz, V. (2004). Subduction and terrane collision stabilize the western Kaapvaal Craton tectosphere 2.9 billion years ago. Earth and Planetary Science Letters, 222, 363-376.

Tobisch, O.T., Barton, M.D., Vernon, R.H. and Paterson, S.R. (1991). Fluidenhanced deformation: transformation of granitoids to banded mylonites, western Sierra Nevada, California, and southeastern Australia. Journal of Structural Geology, 13, 1137-1156.

Werner, C.D. (1987). Saxonian granulites - igneous or lithogenous A contribution to the geochemical diagnosis of the original rocks in the high-metamorphism complexes. In: H. Gerstenberger (Editor), Contributions to the geology of the Saxonian granulite massif (Sächsisches Granulitgebirge), Zfl-Mitteilungen, 133, 221-250.

Winchester, J.A. and Floyd, P.A. (1977). Geochemical discrimination of different magma series and their differentiation products using immobile elements. Chemical Geology, 20, 325-343.

Zimmermann, O.T. (1994). Aspects of the geology of the Kraaipan Group in the Northern Cape Province and the Republic of Bophuthatswana Unpublished MSc thesis, University of the Witwatersrand, Johannesburg, South Africa, 145pp.

Editorial handling: L. D. Ashwal 